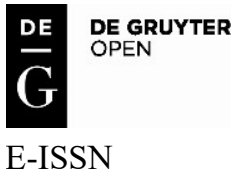

E-ISSN

2450-8594
CIVIL AND ENVIRONMENTAL ENGINEERING REPORTS

CEER 2018; 28 (1): 182-193

DOI: $10.2478 /$ ceer-2018-0015

Original Research Article

\title{
TECTONIC AND GLACIOTECTONIC DEFORMATIONS IN THE AREAS OF POLISH LIGNITE DEPOSITS
}

\author{
Marek WIDERA ${ }^{1}$ \\ Adam Mickiewicz University, Poznań, Poland
}

\begin{abstract}
This study addresses the complex geology caused mainly by tectonic and glaciotectonic processes in lignite-bearing areas of Poland. Tectonics played a dominant role in the deformation of peat/lignite seams during their deposition. This is especially true for deep grabens where the thickest lignite seams were deposited (e.g., Bełchatów). Conversely, glaciotectonics led to the post-depositional deformation of other deposits (e.g., Sieniawa). The effects of tectonic and glaciotectonic processes in this region are investigated using both simplified geological cross-sections and photography. The size, depth and architecture of the glaciotectonic structures verified in this study demonstrate the importance of their consideration during the exploration and exploitation stages of such lignite deposits, as well as the planning of construction projects in areas strongly transformed by glaciotectonics.
\end{abstract}

Keywords: lignite, geology of lignite deposits, tectonics, glaciotectonics, Poland

\section{INTRODUCTION}

Poland is one of the most significant lignite producers in the European Union and worldwide with annual extraction reaching up $60 \mathrm{Mt}$, which supplies about $1 / 3$ of total domestic electricity [21]. Polish lignite production is currently in operation in five mines and eight opencasts (Fig. 1). In order of importance, these mines include: the Bełchatów Lignite Mine (Bełchatów and Szczerców opencasts), Konin Lignite Mine (Jóźwin IIB, Drzewce and Tomisławice opencasts), Turów Lignite Mine (Turów opencast), Adamów Lignite Mine (Adamów opencast) and

${ }^{1}$ Corresponding author: Adam Mickiewicz University, Institute of Geology, Bogumił Krygowski s 12, 61-680 Poznań, Poland, e-mail: widera@amu.edu.pl, tel. +48618296030 
the Sieniawa Lignite Mine (Sieniawa opencast). Furthermore, the Oczkowice lignite deposit, which is located between Poznan and Wrocław, is also discussed here due to its very complex geology with evidence of glaciotectonic deformation (Fig. 1).

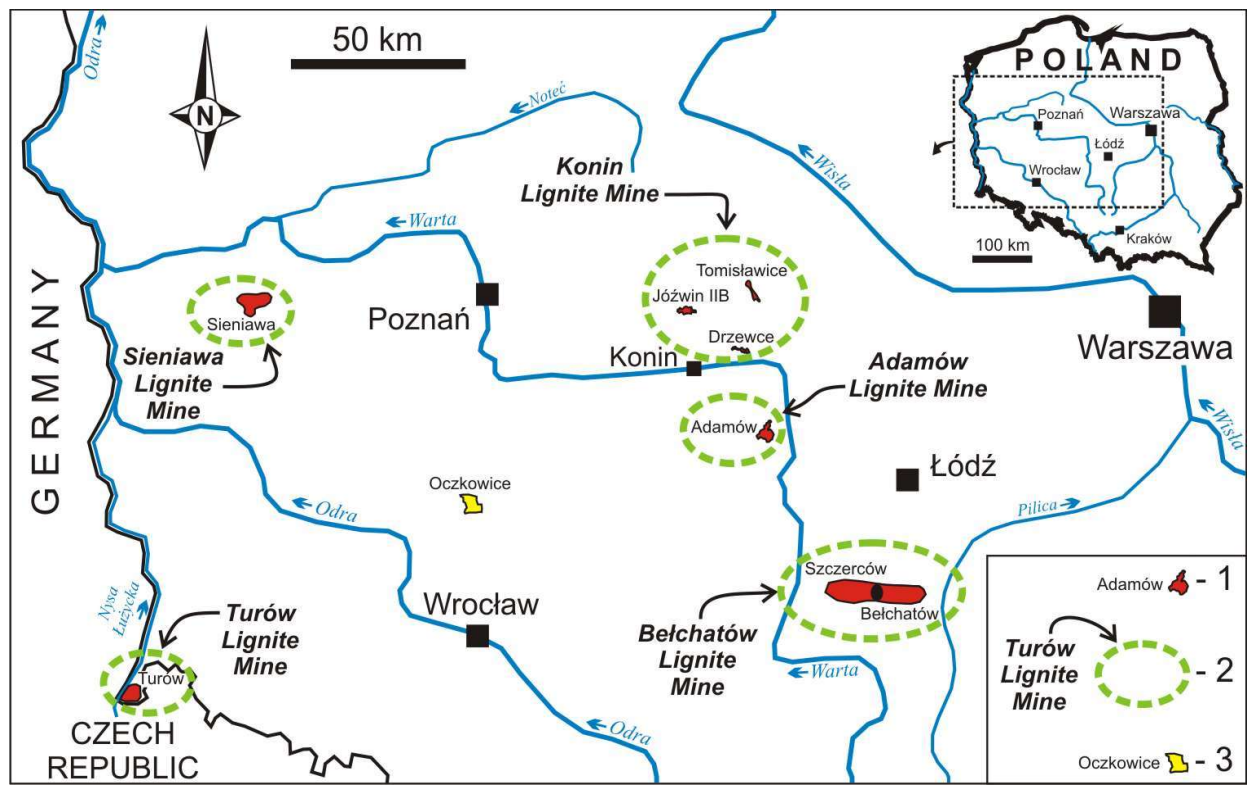

Fig. 1. Location map [17, 21, 23]; 1 - operating lignite opencast mine in November 2017, 2 - area of the operating lignite mine, 3 - lignite deposit examined also in this paper

The aim of the current study is to summarise and compare the complex geology, namely tectonics and glaciotectonics, of selected lignite-bearing areas in Poland. These regions were affected mostly by tectonic movements during the Neogene and glaciotectonic processes in the Quaternary.

\section{OUTLINE OF GEOLOGY}

All exploited lignites in Poland represent humic low rank coal (i.e., ortholignite) [10]. The dominant part of these deposits was formed in low-lying mires that covered the Polish Lowlands during the Neogene [17]. The exploited lignite seams are of the early and middle Miocene age. They stratigraphically represent the third Ścinawa lignite seam (ŚLS-3), second Lusatian lignite seam (LLS-2), and first Mid-Polish lignite seam (MPLS-1) [11, 16-19].

Polish lignite deposits are likely the most genetically differentiated examples in the world. Their formation was influenced by geological factors including 
epeirogenic and tectonic movement, salt and carbonate karstification, erosion, compaction and glaciotectonics $[3,9,16,18,19]$. The majority of the exploited and extractable lignite deposits occur within grabens. The Polish lignite seams are thus characterised by extremely varied thicknesses that range from a few to more than $250 \mathrm{~m}[18,19]$.

\section{DATA AND METHODS}

The localities discussed in this contribution have been intensively explored due to their lignite-rich content. The number of borehole profiles where lignite seams have been drilled ranges from a few hundreds to more than 3000 [6, 8, 16, 18-21]. In order to realistically achieve the objectives of this study, only a few tens of the aforementioned borehole profiles were selected in order to construct generalised cross-sections. All boreholes pierced the lignite seam and occasionally reached the sub-Cenozoic basement (Figs. 2-5).

Field observations made over the past decade play an equally important role in this study. During this time, a great number of glaciotectonic deformation structures were identified and documented by photographs, some of which are included here (Figs. 6-9). The basic parameters of these deformations were measured in opencasts mines with the intention to reconstruct the directions from which the Scandinavian ice sheets came into the study areas (Fig. 10).

\section{TECTONICS VS. GLACIOTECTONICS}

In this section, the complex geology of the lignite-bearing areas is discussed in terms of tectonic and glaciotectonic processes. The effects are well presented by geological cross-sections in some cases, and by photographs in others.

\subsection{Cross-sections}

The best examples of areas affected by tectonic processes are the Bełchatów and Szczerców lignite deposits that cover the Kleszczów Graben in central Poland (Figs. 1, 2). This feature is significant for at least four reasons. First, the graben basement is built by Zechstein, Jurassic and Cretaceous rocks. Second, it is the deepest $(>500 \mathrm{~m})$ Cenozoic graben in the Polish Lowlands $[6,20]$. Third, the graben is divided into two parts by the Dębina Salt Dome and the lignite deposit is further separated into two main segments, Bełchatów and Szczerców. Forth, the total thickness of continuous lignite seams reaches $250 \mathrm{~m}$, which is the largest in the world $[16,18,19]$. 


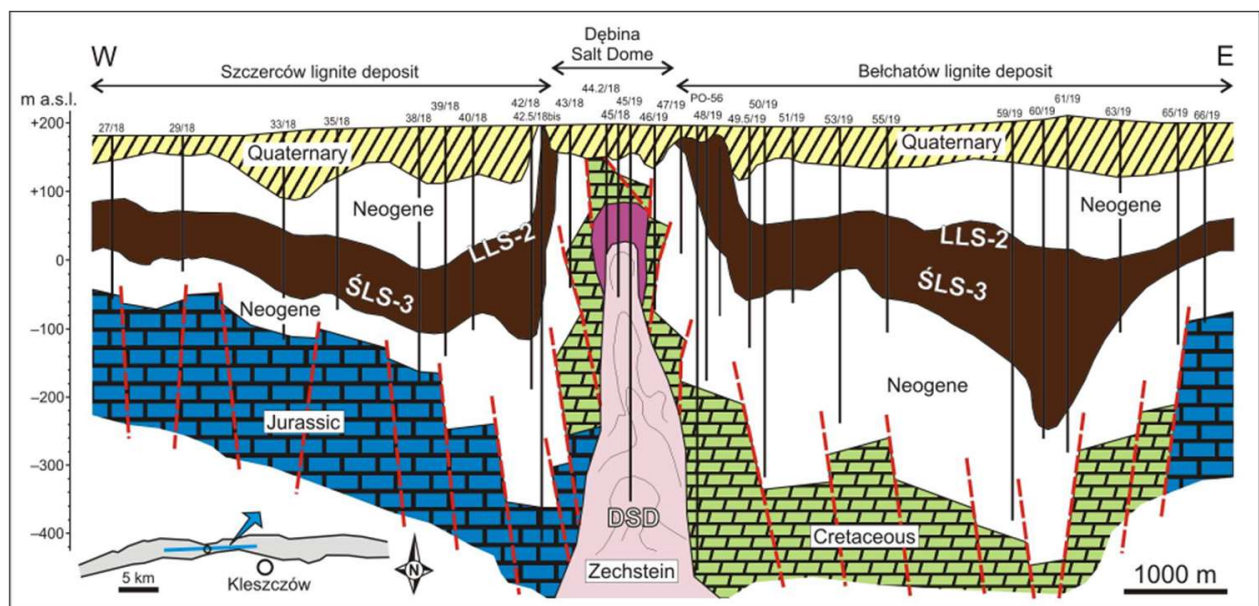

Fig. 2. Cross-section through the thickest lignite seams (summarized thickness of ŚLS-3 and LLS-2) in the Bełchatów and Szczerców deposits $[6,18,20]$; ŚLS-3 - the $3^{\text {rd }}$

Ścinawa lignite seam, LLS-2 - the $2^{\text {nd }}$ Lusatian lignite seam, DSD - Dębina Salt Dome; for location see Fig. 1

The next cross-section, which samples through the Turów lignite deposit, clearly shows the influence of tectonics on the architecture of lignite seams (Fig. 3). The Turów lignite deposit covers the Polish part of the Zittau Basin in southwesternmost Poland (see Fig. 1). This tectonosedimentary basin is between 200 and 400 $\mathrm{m}$ deep, where its crystalline basement lies from $80 \mathrm{~m}$ b.s.l. to more than $300 \mathrm{~m}$ a.s.l. (Fig. 3) [8]. The most tectonically affected seams are the ŚLS-3, with a maximum thickness of $35 \mathrm{~m}$, and the lower bench (b) of the LLS-2 (i.e., LLS-2b). On the other hand, the upper bench of LLS-2 (LLS-2a) is deformed both by tectonic and glaciotectonic processes. The total thickness of LLS-2 reaches up to 70 m (Fig. 3) [8, 18].

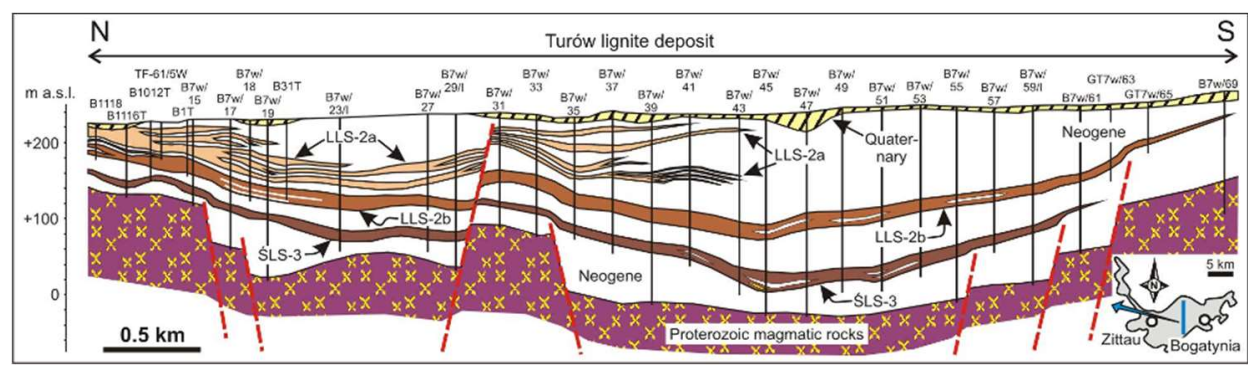

Fig. 3. Cross-section through the Turów lignite deposits; ŚLS-3 - the $3^{\text {rd }}$ Ścinawa lignite seam, LLS-2b - the $2^{\text {nd }}$ Lusatian lignite seam (lower bench), LLS-2a - the $2^{\text {nd }}$ Lusatian lignite seam (upper bench); for location see Fig. 1 
The cross-section through the Oczkowice deposit presents evidence of both tectonic and glaciotectonic processes on the lignite seam architecture (Fig. 4). First, the ' 0 ' lignite seam in Oczkowice is thicker between faults (i.e., fault zones) in the sub-Cenozoic basement. Second, this lignite seam is also glaciotectonically disturbed within the same area. Third, the remaining lignite seams outside of the fault zones lie almost horizontally or their shape corresponds to the depression in the Mesozoic top (Fig. 4).

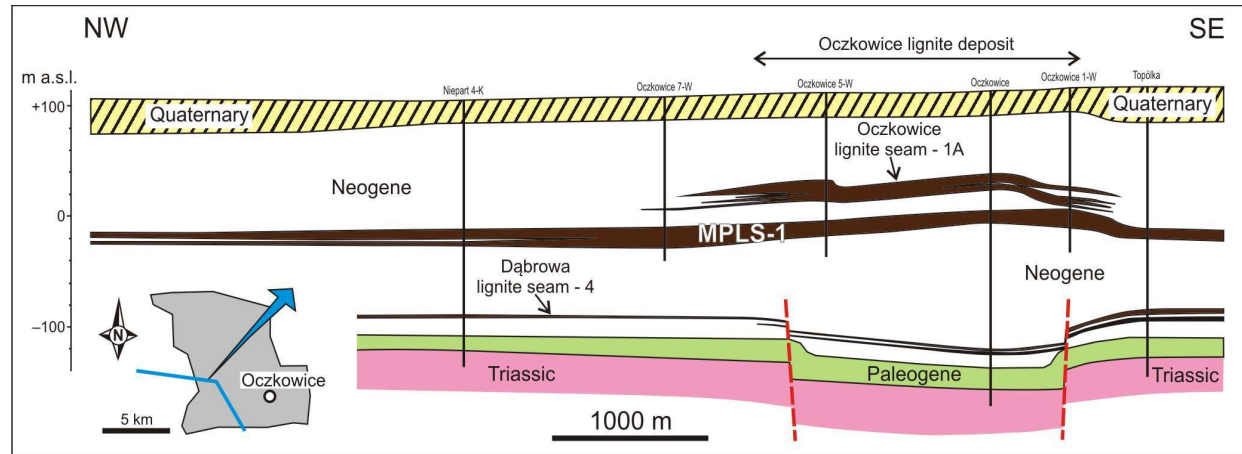

Fig. 4. Cross-section through the Oczkowice lignite deposit [14]; MPLS-1 - the $1^{\text {st }}$ MidPolish lignite seam; for location see Fig. 1

In contrast to the aforementioned cross-sections, the Sieniawa lignite deposit presents only the effects of glaciotectonic processes (Fig. 5). Deformation caused by the Scandinavian ice sheets is clearly visible within cross-sections from this location. The first example shows an upright and symmetrical fold with a height of $\sim 150 \mathrm{~m}$ (Fig. 5a), while the second reveals a thrust (Fig. 5b). In the latter case, the continuity of the lignite seam is interrupted, which results in the separation of the lignite layers by Quaternary sediments in some of the boreholes, e.g. 54/55 (Fig. 5b).

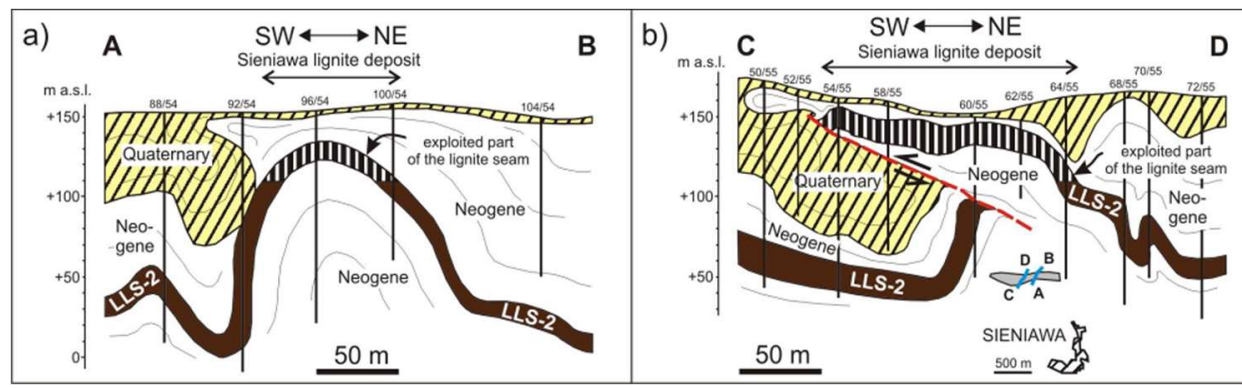

Fig. 5. Cross-sections through the Sieniawa lignite deposit - saddle IX: a) fold, b) thrust $[16,19]$; MPLS-1 - the $1^{\text {st }}$ Mid-Polish lignite seam; for location see Fig. 1 


\subsection{Field observations}

Konin and Adamów lignite mines. The Neogene and Quaternary deposits from the Konin and Adamów lignite mines are among the most examined to have undergone glaciotectonic deformation [4, 12-15, 22-25]. A large number of

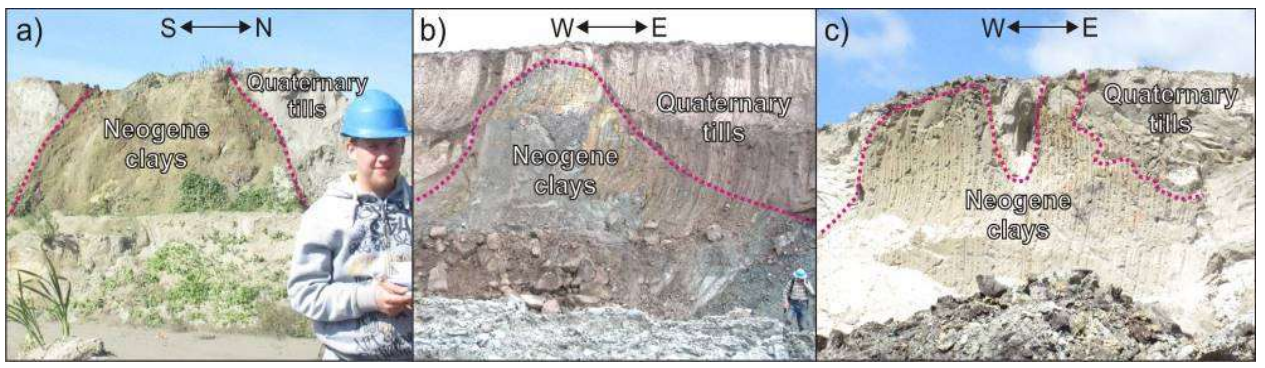

Fig. 6. Glaciotectonically folded the Neogene clays within the Quaternary deposits present in the Konin and Adamów lignite mines in central Poland; opencasts: a) Drzewce, b) Jóźwin IIB, c) Adamów

glaciotectonic structures have been previously reported. These structures differ in size with heights ranging from a few $\mathrm{mm}$ to several tens of metres. Both the Neogene (lignite, clays) and Quaternary (tills) deposits were involved in glaciotectonic deformation (folds, thrusts, nappes, etc.) [15, 22]. The most commonly observed glaciotectonic structures are folds from the Neogene clays (Fig. 6). Due to the colour contrast (red, yellow, blue), they differ from the

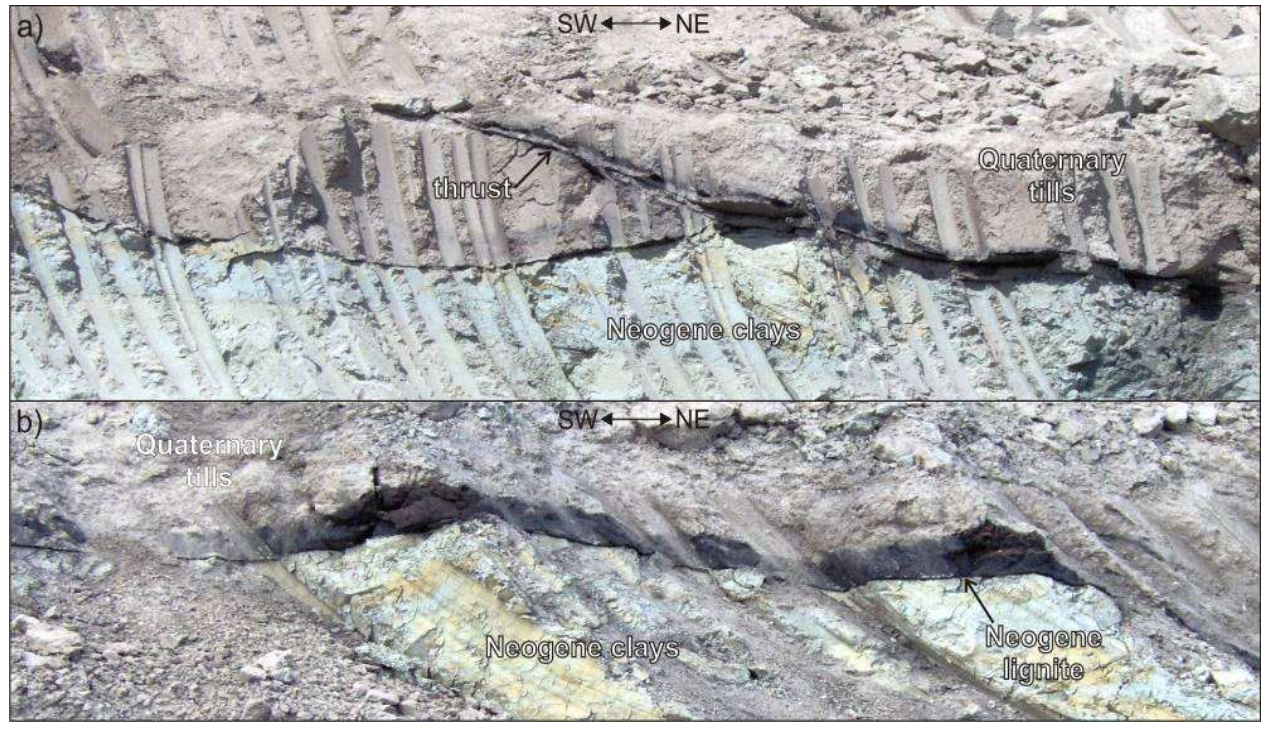

Fig. 7. Glaciotectonic deformations in the Jóźwin IIB opencast, Konin Lignite Mine in central Poland: a) thrust, b) inversion of the Neogene clays and lignites 
predominantly grey glacial tills (Figs. 6,7). The thrusts are also well developed (Fig. 7). The first thrust example shows the incorporation of the Neogene clays within the Quaternary tills along the thrust plane (Fig. 7a). However, the second example contains a stratigraphic inversion of the Neogene deposits (i.e., older lignites rest on younger clays) and is therefore more interesting (Fig. 7b).

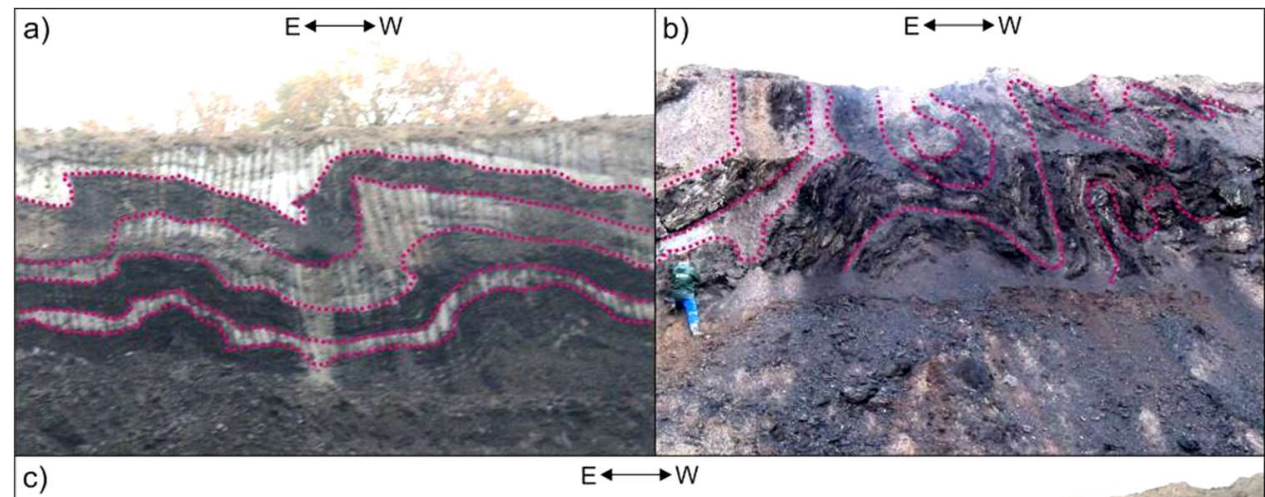

c)

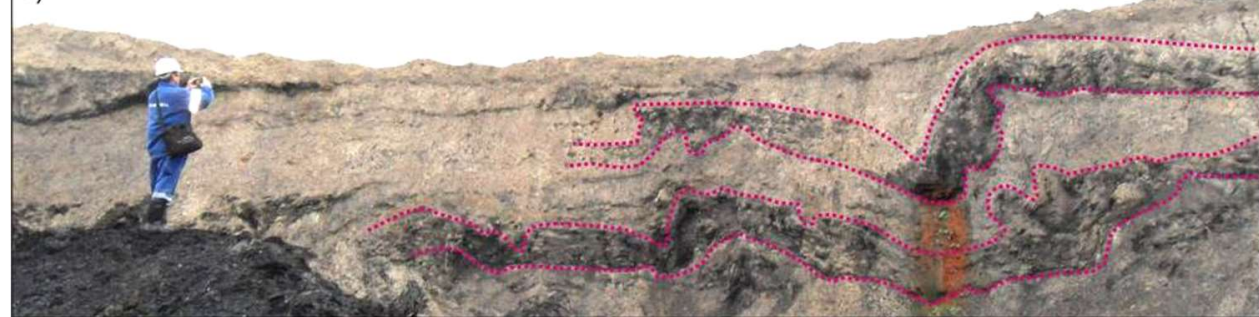

Fig. 8. Glaciotectonically folded the Neogene clays and lignites of LLS-2 - upper bench in the Turów opencast in south-western Poland: a) overturned and asymmetrical fold, b) disharmonic fold, c) asymmetrical and disharmonic fold

Turów Lignite Mine. Glaciotectonic processes are the least expressed in the Turów Lignite Mine due to its location (Fig. 1) where the thickness of the Scandinavian ice sheet was relatively small. The depth of the glaciotectonic deformation reaches up to a dozen metres from the surface. These structures represent the majority of the various types of folds and are very visible due to the contrasting colours of black lignites and white to light grey clayey intercalations (Fig. 8).

Sieniawa Lignite Mine. Regardless of the fact that the Sieniawa lignite deposits are the best example of the glaciotectonic structures in Poland $[3,9,16,19]$, it is also possible to identify clearly developed deformational structures in the field. Because the glaciotectonic deformation structures observed in the Sieniawa lignite opencasts are the subject of a separate contribution included in this volume, they are only mentioned briefly in this paper. In general, the main lignite seam (LLS-2) in the area is strongly folded and sliced (Fig. 9). 


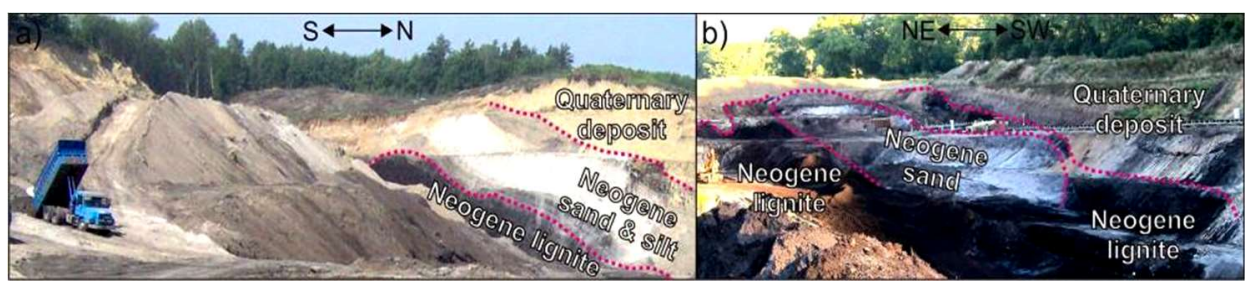

Fig. 9. Glaciotectonically folded lignites of LLS-2 in the Sieniawa opencast in western Poland: a) saddle IX in 2010 - closed, b) saddle VIII in 2015 - currently operating

The depth of this deformation reaches more than $200 \mathrm{~m}$ from the present ground surface. However, the uppermost parts of the lignite seam, the so-called 'lignite saddles' that lie above the groundwater level, are exploited at the Sieniawa lignite mine. Therefore, only limited parts of the glaciotectonic structures can be investigated (Fig. 9).

Directions of ice sheet movement. The direction of ice sheets was reconstructed assuming that movement was perpendicular to the strike of folds and thrusts [1, $2,5,7]$. Appropriate measurements, using a geological compass and calculations, were made for each of the aforementioned lignite opencast mines. The results obtained from Konin and Adamów have already been partially published [4, $12,13,22-25]$, but those from the Turów and Sieniawa are quite new. In order to provide a better visualisation, all results are presented graphically in Fig. 10.

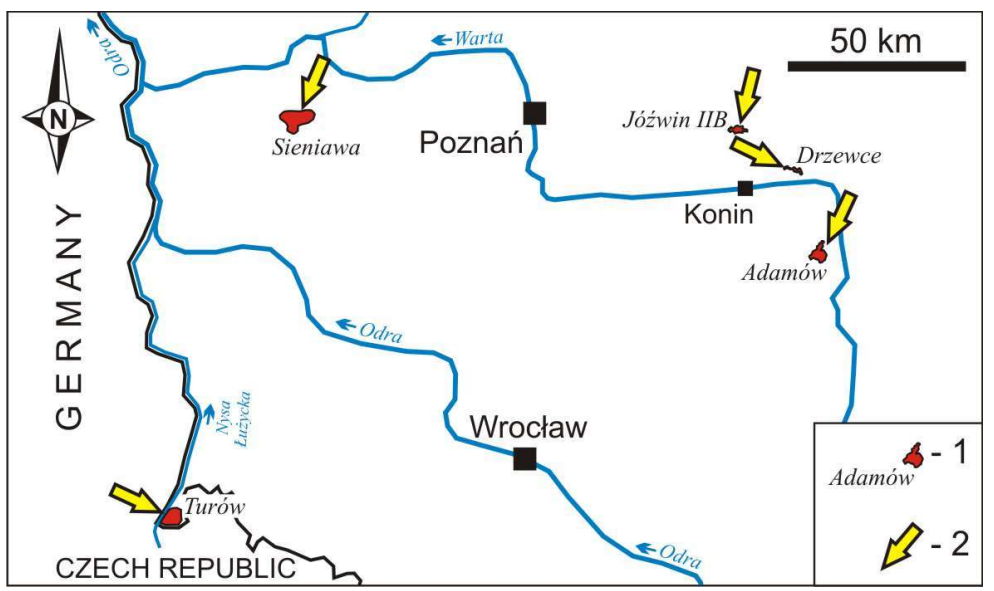

Fig. 10. Directions of ice sheet movement [23]; 1 - measurements made in most currently operating Polish lignite opencast mines, 2 - reconstructed from glaciotectonic structures mean azimuth of the ice sheet advance; for more information see Fig. 1

The directions of the Scandinavian ice sheet advance into the area of currently exploited lignite deposits in Poland differ considerably. Generally, they should be from the north to the south in the Polish Lowlands. The results of the 
reconstructed mean azimuth of the ice sheet advance are as follows: Drzewce -

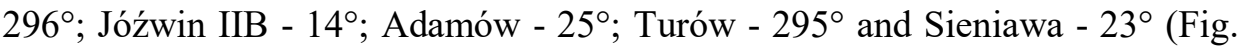
10). The majority of the differences in the local deformation direction can be explained by the elongation and location of tectonic dislocations in the deeper sub-Cenozoic basement $[22,23]$. Apart from the Sieniawa lignite opencast, the remaining opencasts show a close relationship between tectonics and glaciotectonics. However, the best examples investigated here are the Drzewce and Adamów opencasts where the glaciotectonic structures are exactly perpendicular to the elongation of the tectonic grabens (Fig. 10).

\section{FINAL REMARKS}

Several generalisations can be given here about the influence of tectonic and glaciotectonic processes on lignite-bearing areas in Poland. As shown in this study, the documented and exploited lignite deposits provide a good opportunity to investigate both tectonic and glaciotectonic deformations.

Tectonic processes that strongly disturbed the lignite architecture took place syndepositionally, when the peat/lignite seams were formed. Therefore, the lignite floor is greatly morphometrically differentiated and the Polish lignite seams are the thickest in the world, reaching up to $250 \mathrm{~m}$ (ŚLS-3 and LLS-2) in the case of Bełchatów.

In all lignite opencasts currently operating in Poland, glaciotectonic structures formed by the Scandinavian ice sheets can be observed. In contrast to tectonic processes, glaciotectonics affected the lignite seams post-depositionally. In most cases, only the upper lignite layers are deformed. The Sieniawa lignite deposit is an exception where the entire lignite seam (LLS-2) was glaciotectonically transformed into folds and thrusts.

In conclusion, the areas containing Polish lignite deposits are characterised by complex geology including both tectonic and glaciotectonic deformation structures. These structures may be hazardous to mining activities (i.e., during exploration and exploitation), as well as to the construction industry. In the former scenario, the presence of deformation structures of variable origins requires the use of appropriate equipment and planning of operation directives that take different types of discontinuities and dipping angles of rock layers into account. In the latter case, deformational structures located at relatively shallow depths (i.e., close to the ground surface) are particularly dangerous.

\section{ACKNOWLEDGEMENTS}

The author is deeply grateful to the Turów and Sieniawa lignite mines for providing the geological data as well as Figures $5 \mathrm{a}$ and 9b, respectively. 


\section{REFERENCES}

1. Aber J.S., Ber A.: Glaciotectonism. Developments in Quaternary Science 6, Amsterdam, Elsevier 2007.

2. Brodzikowski K.: Glacial deformation environment in the subsiding zone with special references to the Kleszczóww tectonic graben, Quaternary Studies in Poland, 6 (1985) 5-22.

3. Ciuk E.: Types of brown coal deposits within coal-bearing formations of continental Tertiary of Poland, 23rd Geological Congress, Prague, (1968) 119-134.

4. Dżumak J.: Analiza mezostrukturalna deformacji glacitektonicznych $w$ odkrywkach KWB Konin S.A., Praca magisterska, Archiwum Instytutu Geologii UAM, Poznań, (2008) 1-54.

5. Eissmann L.: Quaternary geology of eastern Germany (Saxony, SaxonAnhalt, South Brandenburg, Thuringia), type area of the Elsterian and Saalian Stages in Europe, Quaternary Science Reviews, 21 (2002) 12751346.

6. Gotowała R., Hałuszczak A.: The Late Alpinie structural development of the Kleszczów Graben (Central Poland) as a result of a reactivation of the preexisting, regional dislocation. EGU Stephan Mueller Special Publication Series, 1 (2002) 137-150.

7. Jaroszewski W.: Rozważania geologiczno-strukturalne nad geneza deformacji glacitektonicznych. Annales Societatis Geologorum Poloniae, 61 (1991) 153-206.

8. Kasiński J.R.: Atlas geologiczny trzeciorzędowej asocjacji brunatnowęglowej w polskiej cześci niecki żytawskiej 1:50 000, Warszawa, Państwowy Instytut Geologiczny 2000.

9. Kasiński J.R., Piwocki M.: Low rank coals in Poland: prospection, mining, progress, In: Jureczka J., Podemski M. (Eds.), Proceedings of the IV European Coal Conference, Polish Geological Institute Special Papers, 7 (2002) 18-30.

10. Kwiecińska B., Wagner M.: Typizacja cech jakościowych wegla brunatnego $z$ krajowych złóż wedlug kryteriów petrograficznych $i$ chemicznotechnologicznych dla celów dokumentacji geologicznej złóż oraz obstugi kopalń, Kraków, Wydawnictwo Centrum PPGSMiE Polskiej Akademii Nauk 1997.

11. Piwocki M., Ziembińska-Tworzydło M.: Neogene of the Polish Lowlands lithostratigraphy and pollen-spore zones, Geological Quarterly, 41 (1997) 21-40.

12. Prusinowski M.: Budowa geologiczna rejonu odkrywki węgla brunatnego Koźmin, Praca magisterska, Archiwum Instytutu Geologii UAM, Poznań, (2001) 1-99. 
13. Stępień B.: Deformacje osadów kenozoicznych w zachodniej ścianie odkrywki Koźmin KWB ,Adamów”, Landform Analysis, 30 (2015) 29-40.

14. Urbański P., Widera M.: Geologia złóż węgla brunatnego w poludniowozachodniej Wielkopolsce, Przegląd Geologiczny, 64 (2016) 791-798.

15. Widera M.: Stratigraphy and lithology of Quaternary sediments in the Kleczew region and in key sections of the eastern Wielkopolska Lowland, central Poland, Geological Quarterly, 44 (2000) 211-220.

16. Widera M.: Changes of the lignite seam architecture - a case study from Polish lignite deposits, International Journal of Coal Geology, 114 (2013) 60-73.

17. Widera M.: An overview of lithotype associations forming the exploited lignite seams in Poland, Geologos, 22 (2016) 213-225.

18. Widera M.: Characteristics and origin of deformations within the lignite seams - a case study from Polish opencast mines, Geological Quarterly, 60 (2016) 179-189.

19. Widera M.: Genetic classification of Polish lignite deposits: A review, International Journal of Coal Geology, 158 (2016) 107-118.

20. Widera M., Hałuszczak A.: Stages of the Cenozoic tectonics in central Poland: examples from selected grabens, Zeitschrift der Deutschen Gesellschaft für Geowissenschaften, 162 (2011) 203-214.

21. Widera M., Kasztelewicz Z., Ptak M.: Lignite mining and electricity generation in Poland: The current state and future prospects, Energy Policy, 92 (2016) 151-157.

22. Widera M., Włodarski W.: Makroskalowe deformacje glacitektoniczne osadów neogeńskich $w$ konińskich odkrywkach węgla brunatnego, Zeszyty Naukowe Uniwersytetu Zielonogórskiego, Inżynieria Środowiska, 139 (2010) 126-135.

23. Widera M.: Areas of lignite deposits with complex geology - some examples from Poland, CGE-2017 - 2nd Second International Conference "Challenges in Geotechnical Engineering". November 20th-23th 2017, Kyiv, Ukraine (2017) 44-46.

24. Włodarski W.: Litologia, stratygrafia i glacitektonika dolnego i środkowego czwartorzędu, In: Skoczylas J., Biernacka J. (Eds): Geologia i ochrona środowiska Wielkopolski. Przewodnik LXXI Zjazdu PTG, Poznań, Bogucki Wydawnictwo Naukowe, (2000) 112-121.

25. Włodarski W.: Geometry and kinematics of glaciotectonic deformation superimposed on the Cenozoic fault-tectonic framework in the central Polish Lowlands, Quaternary Science Reviews, 94 (2014) 44-61. 


\section{TEKTONICZNE I GLACITEKTONICZNE DEFORMACJE NA OBSZARACH POLSKICH ZŁÓŻ WĘGLA BRUNATNEGO}

\section{Streszczenie}

Prezentowana praca poświęcona jest złożonej geologii, spowodowanej głównie przez procesy tektoniczne i glacitektoniczne, wybranych obszarów węglonośnych w Polsce. Tektonika odgrywała fundamentalną rolę deformującą pokłady torfu/węgla brunatnego w czasie ich depozycji. Dotyczy to zwłaszcza głębokich rowów tektonicznych, w których zalegają najgrubsze pokłady węglowe, np. złoża: Bełchatów, Szczerców, Turów, Lubstów, Pątnów I-IV, Adamów, itd. Natomiast glacitektonika prowadziła do postsedymentacyjnych deformacji polskich pokładów węgla brunatnego. W większości przypadków rola destukcyjna procesów glacitektonicznych była niewielka, w niektórych przypadkach znacząca, a nawet dominująca, np. na obszarze złoża Sieniawa. Skutki procesów tektonicznych i glacitektonicznych przedstawiono na uproszczonych przekrojach geologicznych (złoża: Bełchatów, Szczerców, Oczkowice, Sieniawa), a także na fotografiach wykonanych w niektórych odkrywkach eksploatowanych aktualnie złóż (odkrywki: Jóźwin IIB, Drzewce, Adamów, Turów, Sieniawa). O ile tektonika dotknęła głównie spągowe warstwy pokładów węglowych, o tyle glacitektonika doprowadziła do deformacji ich partii stropowych. Zróżnicowane rozmiary, głębokość zalegania i bogactwo struktur glacitektonicznych sprawia, że należy brać je pod uwagę na etapie dokumentowania złóż, ich eksploatacji, czy też planowania inwestycji budowlanych na obszarach silnie przekształconych glacitektonicznie.

Słowa kluczowe: węgiel brunatny, geologia złóż węgla brunatnego, tektonika, glacitektonika, Polska

Editor received the manuscript: 27.11.2017 